ÇOMÜ Uluslararası Sosyal Bilimler Dergisi 4(1), 1-28, 2019

COMU International Journal of Social Sciences 4(1), 1-28, 2019

\title{
Regional Integration via Major Powers: Russian Eurasian Economic Union versus Chinese Silk Road Economic Belt versus American New Silk Road Project*
}

\author{
Otabek OMONKULOV ${ }^{* \oplus}$
}

Gürol BABA***

\begin{abstract}
Great and regional powers have been trying to influence/control Central Asia's (CA) political-economic fabric and development for the sake of their own strategic interests via different politico-economic schemes. Especially, Russia, China and the US are competing to inject their individual regional integration models for reducing the influence of other great and regional powers. These models fall in the category of extra-regional integration projects, which promote different structured approaches. This paper explores the viability and major impacts of great power-induced regional integration and their repercussions. It argues that these projects are developed by and biased towards preserving the influence of major powers, and lack viable framework to bring both global and regional players into a path of long-term cooperation. Even if the great powers' regional integration approaches are divergent from each other, their common point the asymmetry they apply when they are approaching the region. Primarily they prioritized their own strategic interests while discarding CA states' expectations to a significant extent. However, if implemented successfully, it cannot be ruled out that these projects may bring socioeconomic benefits to CA countries at the expense of political independence.
\end{abstract}

Keywords: Central Asia, Regional Integration, Eurasian Economic Union, Silk Road Economic Belt, New Silk Road.

\section{Büyük Güçler Aracılığıyla Bölgesel Bütünleşme: Rusya'nın Avrasya Ekonomik Birliği, Çin'in İpek Yolu Ekonomik Kuşağı ve ABD’nin Yeni İpek Yolu Projesi}

Öz

Büyük ve bölgesel güçler kendi stratejik çıkarları için çeşitli siyasal ve ekonomik projeler aracilığıla Orta Asya'nın (OA) siyasi-ekonomik dokusu ve kalkınması üzerinde bir etki/ kontrol kurmaya çalışmaktadırlar. Özellikle, Rusya, Çin ve ABD kendilerine özgü bölgesel bütünleşme modelleri sunarak bölgenin üzerinde bir tekel haline gelmek için mücadele etmektedir. Ayrıca, bu güçler son on yıldır çeşitli bölge dışı bütünleşme projelerini sürekli bir şekilde geliştirmektedir. OA için yapılandırılmış bölgesel bütünleşme modellerini öneren

This paper is based on the preliminary findings of a doctoral dissertation which is being written by Otabek Omonkulov under the supervision of Gürol Baba as partial fulfillment of the requirements of PhD degree in International Relations at Canakkale Onsekiz Mart University. Initial power point version of the paper was verbally presented at the 1st International Students Social Sciences Congress which was held in Ankara, between 16-17 May 2015 with the cooperation of the Presidency for Turks Abroad and Related Communities and Hacettepe University.

** PhD Student, Department of International Relations, Biga Faculty of Economics and Administrative Sciences, Canakkale Onsekiz Mart University, otobekomon@stu.comu.edu.tr

(c) Corresponding author

*** Assoc. Prof. Dr., Social Sciences University of Ankara, Political Science Faculty member in the Department of International Relations, gurol.baba@asbu.edu.tr 
ve destekleyen mezkûr güçler günümüzde rekabet halinde olan üç büyük bütünleşme projesini gündeme getirmektedir. Bunlar Rusya'nın Avrasya Ekonomik Birliği projesi, Çin'in İpek Yolu Ekonomik Kuşağı projesi ve ABD'nin Yeni İpek Yolu projesidir. Bu makalede büyük güçlerin bölgesel bütünleşme yaklaşımları incelenmekte ve bu bütünleşme projelerinin $O A^{\prime} d a$ sürdürülebilirliği ve bölge üzerindeki etkileri analiz edilmektedir. Makalede, büyük güçler tarafindan ve onların çıkarlarını koruyacak şekilde geliştirildiğinden dolayı, bu projelerin bölgesel ve küresel oyuncuları bir araya getirip işbirliğine teşvik edici bir pratik çerçeve sunamayacağı sonucuna varılmaktadır. Bu bağlamda her büyük gücün bölgesel bütünleşme yaklaşımının bir birinden farklı olduğunun alt çizilmekte, öte yandan bölgeye yaklaşımlarında bölge ülkelerinin beklentilerinden ziyade kendi çıkarlarını ön plana almaları açısından benzerlik bulunduğu öne sürülmektedir. Ancak bu projeler başarıyla hayata geçirilse, OA devletlerinin siyasi bağımsızlığını gölgelemekle birlikte bölge ülkelerine sosyoekonomik yararlar sağlayabileceği göz ardı edilemez.

Anahtar Kelimeler: Orta Asya, Bölgesel Bütünleşme, Avrasya Ekonomik Birliği, İpek Yolu Ekonomik Kuşağı, Yeni İpek Yolu.

\section{INTRODUCTION}

Central Asia (CA), being located at the heart of Eurasia, has become one of the most strategic regions of the modern world. Particularly, after the collapse of the Soviet Union major great powers such as Russia, China and the US and someregional powers have been trying to influence or even dominate the region's politico-economicfabric and development for their own strategic interests via various projects. ${ }^{1}$ These projects, namely, the Russian-led Eurasian Economic Union (EAEU), the Chinese initiated Silk Road Economic Belt (SREB), and the American initiated New Silk Road (NSR), are naturally in competition with each other. These structured models of regionalism individually focus on broader regional integration in order to control the politico-economic processes of CA countries in a single scheme. What makes these projects similar is that they are all initiated by great powers.

The main purpose of this paper is to comparatively analyze the EAEU, BRI and NSR. This paper also examines the viability and implications of these projects in CA. At first glance, comparing a formal regional economic union like Russian EAEU with Chinese $\mathrm{BRI}$ and American NSR projects may seem problematic, since the first is known as a proper regional integration process while the latter two are sometimes perceived as mere development-based cooperation initiatives. In essence this perception is inaccurate.

1 There are huge numbers of literature on the strategic rivalries among the regional, global powers over Central Asia which support our abovementioned claim. See: Rumer, E., Trenin, D. and Zhao, H. (2007). Central Asia: Views from Washington, Moscow and Beijing. Armonk and London: ME Sharpe; Wishnick, E. (2009). Russia, China, and the United States in Central Asia: Prospects for great power competition and cooperation in the shadow of the Georgian crisis. Strategic Studies Institute. Retrieved from https:// ssi.armywarcollege.edu/pdffiles/PUB907.pdf (Accessed: 2019, January 3); Laruelle, M. et al. (2010). China and India in Central Asia: A new "Great Game"?. New York: Palgrave Macmillan; Blank, S. (2012). Whither the new great game in Central Asia? Journal of Eurasian Studies, 3(2), pp.147-160; Kim, Y., Blank, S. (2013). Same bed, different dreams: China's 'peaceful rise' and Sino-Russian rivalry in Central Asia. Journal of Contemporary China, 22(83), pp.773-790; Cheng, Y. (2015). The Eurasian moment in global politics: a comparative analysis of great power strategies for regional integration. In P. Dutkiewicz and R. Sakwa (eds.), Eurasian integration - the view from within (pp.274-290). London and New York: Routledge; International Crisis Group, (2017). Central Asia's Silk Road rivalries. Europe and Central Asia Report, 245; Ataman, M. (ed). (2018, Fall). The struggle over Central Asia: Chinese-Russian rivalry and Turkey's comeback. Special edition of Insight Turkey, 20(4), Retrieved from https://www.insightturkey. com/issues/2018/20/4 (Accessed: 2019, January 3). 
Cooperation is the first prerequisite of any regional integration. The EAEU seems to imitate the process of economic integration by the European Union (EU). For instance, it upholds some of the integration rules and has some institutions and governing norms. Practically, it has little to do with actual regional economic integration like the EU. However, this paper refers to EAEU as an evolving regional integration process.

In addition, the Chinese and the American approaches are more than development-based initiatives. Likewise EAEU, they are Great Power Regionalism strategies which could turn to formal regional integration processes if needed, depending on the political will and economic priorities of participating countries. Both BRI and NSR highlight an economic or financial integration in the CA as one of their intended goals. This is especially true with BRI, which envisions some degree of regional integration (Huang, 2016; Kaczmarski, 2017:1364; Laruelle, 2018). BRI has already moved forward economic integration by signing number of preferential trade and investment agreements (PTIAs), free trade agreements (FTAs), and free trade zones (FTZs) with the participating countries. It also has reached an economic and trade cooperation pact with EAEU (Wang, 2018; International Crisis Group, 2017). Especially, PTIAs, FTAs and FTZs are considered as a signal of economic integration in the "new regionalism" scholarship (Lombaerde and Söderbaum, 2013). Since they are in their early phases it is difficult to predict whether they will evolve into a conventional regional integration process.

Area studies scholars published a number of pieces on EAEU and BRI (Dragneva and Wolczuk, 2013; Ye, 2015; Dutkiewicz and Sakwa, 2015; Callahan, 2016). However, comparative studies of EAEU and Silk Road initiatives are only newly emerging (Kaczmarski, 2017; Svetlicinii, 2018; Wang, 2018; Ferguson, 2018). Available comparative studies refer (as this paper does) to both EAEU and Silk Road initiatives as great power-imposed complex regionalism projects.

Although the three regional economic integration projects seem to be primarily based on great powers' self-interest, and may be referred to as Great Power Regionalism, we cannot rule out the generation of economic benefits coming from one or more of these projects to the CA countries.

\section{REGIONAL INTEGRATION: A REVIEW OF LITERATURE}

Even if regional integration has been studied in both its conceptualization and theorization for over half a century, there are still unclarities and unresolved debates in its literature. Puchala (1971: 267) noted that "years of defining, redefining, refining, modeling and theorizing have failed to generate satisfactory conceptualizations of" regional integration since "different researchers have been looking at different parts, dimensions and manifestations of the phenomenon" as in the case of metaphoric story of "blind men and elephant." One of these important debates has been between neo-functionalism (Haas and Lindberg) and intergovernmentalism (Hoffmann, 1966). There is also a continuing discourse involving neo-functionalist theory, externality theory (Mattli, 1999, 2012) and contracting theory (Cooley and Spruyt, 2009) of comparative regional integration.

Neo-functionalists believe that integration based on the concept of "spill-over" within "low politics" (certain sectors of economy) between states will subsequently lead to the integration on "high politics" (larger economic and political union). To Lindberg (1963: 
10), "spill-over" refers to "a situation in which a given action, related to a specific goal, creates a situation in which the original goal can be assured only by taking further actions, which in turn create a further condition and a need for more action, and so forth." For neo-functionalist and externality theory, the main promoters of regional integration are sub-national and supranational actors. Governments are facilitators.

On the contrary, intergovernmentalism and contracting theory argue that nation-states are the main actors and they decide, control and determine the level and scope of integration. Sub-national and supranational actors support the state in this endeavor. As Mattli (2012: 790) summarized, "States write integration contracts and supranational institutions deepen integration where they exist." Intergovernmentalism rejects "spill-over effects" as the logic of integration and, instead, proposes that integration will occur only when interests of different states come closer. Cooley and Spruyt (2009) dispute neofunctionalistic explanation of "spill-over" and clarify it as something principally intended and directed by the states. Externality theory (Mattli, 2012: 789) considers that "the presence of a dominant state to be necessary to overcome regional coordination dilemmas and resolve distributional problems" of regional integration process. Haas argues that "symmetrical regional heterogeneity" and willingness to convey some sorts of government authority to supranational actors as the preconditions of successful regional integration. Intergovernmentalism sees asymmetry and "asymmetrical interdependence" in any regional integration and thus skeptical on the transfer of some of the state sovereignty to the supranational body.

Balassa (1961: 1) defines regional economic integration as "a process and as a state of affairs... designed to abolish discrimination between economic units belonging to different national states." Machlup (1977: 3) also defines the regional economic integration as the process of merging single economies with other ones in order to form a larger economic region. Balassa further formulates the evolution of successful regional economic integration in five steps: free-trade area, customs union, common market, economic union, and total economic integration. "Total economic integration", Balassa's the final stage of the evolution of successful regional integration formula, is redefined by Kabananiye (2011: 17) as "political integration, in which member countries hand over their individual sovereignty to a supranational organization."

Haas (1958: 16; 1970: 608) defines regional integration as a process of "political unification" via "non-coercive efforts." Nye (1968: 858) divides the concept of integration into three components. The first and the main component is "economic integration (formation of a transnational economy)." The second and third forms are "social integration (formation of a transnational society) and political integration (formation of transnational political interdependence)." The last two processes usually arise out of successful economic integration. Lindberg (1963: 6) defines political integration as "(1) the process whereby nations forgo the desire and ability to conduct foreign and key domestic policies independently of each other, seeking instead to make joint decisions or to delegate the decision-making process to new central organs; and (2) the process whereby political actors in several distinct settings are persuaded to shift their expectations and political activities to a new center." Jacob and Teune (1964: 4) describe political integration as "a relationship of community among people... a feeling of identity and self-awareness."

Liberal intergovernmentalism (Moravcsik, 1993, 1998) analyses regional integration as 
the three-step process. The first is "national preference formation" where a state determines the major motive (economic or geopolitical interests) behind the integration. The second step is "interstate bargaining" in which the sides discuss "the efficiency and distributional outcomes". Here the interstate agreements on essential issues are based on "asymmetrical interdependence or supranational entrepreneurship." The final step is institutional choice in which states hand over some decision-making power to supranational institutions in order to get supplementary reliable assurance.

Above-mentioned definitions of regional integration are also suitable for Deutsch's (1957) "security communities." In all cases, political integration is supposed to be successful if economically and socially integrated communities have similar identity and culture. It can be summarized that the regional integration is generally characterized as a process, triggered by state (including great powers) or sub and supranational actors, initially starting from economic cooperation to political integration, if successful, culminating to the formation of a distinct economic, social and finally political union (Deutsch 1957; Balassa, 1961; Haas, 1958, 1970; Machlup, 1977, El-Agraa, 1999; Mattli, 1999). Scholars agree that total economic integration or political integration is an uneasy and controversial process in the sense that even some of the EU member states are still reluctant to hand over some of their sovereignty to supranational institutions. It is observable that all regional integration processes have some sort of progress mechanism. In turn, these theoretical as well as practical mechanisms are grounded on some regional integration theories. Regional integration mechanisms are almost analogous with little differences. It should be argued that the considerable numbers of the regional integration theories are based on or encouraged by successful regional integration projects such as the EU, the North American Free Trade Agreement (NAFTA) and the Association of Southeast Asian Nations (ASEAN). Successful regional integration projects, especially the EU experience has also been a source of inspiration for regional integration projects within the post-Soviet space, including Central Asia.

\subsection{Regional Integration in Central Asia: Theory and Practice}

The study of regional integration in CA has a vibrant literature. The literature has two strands. The first one (Metcalf, 1997; Adams, 1998; Libman, 2006; Qoraboyev, 2010; Libman and Vinokurov, 2011) studies CA regional integration in connection with the other post-Soviet sub-regions. The second one (Bobokulov, 2006; Pofmret, 2009; Rakhimov, 2010; Johannes, 2012) focuses on the integration within the region, separating it from the rest of the former Soviet republics. These two groups cover the top-down and bottom-up, formal and informal, state led and firm-centric regional integration processes in Central Asia.

Many scholars (Bartlett, 2001; Geyikdagi, 2005; Bobokulov, 2006; Johannes, 2012) believe that successful regional integration in CA will primarily induce economic growth and could become a remedy to several socio-political and regional security issues. In short, the literature wholeheartedly supports regional integration. Bobokulov (2006) argues that there is no alternative to regional integration for the security and prosperity of Central Asia. Cultural and linguistic similarities as well as growing trend of labor migration, cross-border informal trade are seen as the main facilitators of regional integration (Ivakhnyuk 2006; Libman, 2009).

Yet, there has been little progress in terms of successful regional integration in Central 
Asia over the last three decades. Spechler (2000) described this regional non-cooperation as pathology. There were trials of cooperation patterns but without much of a success. Newly independent republics of Central Asia-Kazakhstan, Uzbekistan, Turkmenistan, Kyrgyzstan and Tajikistan tried several integration projects. Wirminghaus (2012: 25) estimates that "during the two decades between 1991 and 2010... 39 different initiatives of regional integration were proposed of which 36 organizations actually came into being" in the post-Soviet space. Wirminghaus (2012: 27) divides these integration projects into four groups: "Original post-Soviet integration" (Commonwealth of Independent States), Russia-dominated integration (Eurasian Economic Community (EurAsEC), Single Economic Space (SES), Central Asia-centric integration (Central Asian Union, Central Asian Economic Union) and "anti-Russia" integration (GUUAM). Yet, most of these initiatives failed to achieve their stated goals and the remaining ones are also proved ineffective so far.

According to Valovaya (2012: 43) "the main reason for the inefficiency of all these projects was that they formally copied the models of European integration with the creation of similar institutes and the proclamation of similar objectives. In essence, however, these first attempts of integration disregarded the key laws of the integration process." Similarly, Atik (2014: 1326) lists some of the major causes of inefficiency of economic integration projects in post-Soviet space as:

- "Inadequacy in converging with the rules of market economy and in adapting to the world economy;

- Differences in macroeconomic structures (national income and income distribution, industrialization; national and foreign direct investments, foreign trade capacity and balance of payments);

- Regional conflicts of interest and claim of power, lack of common goals, geographical position;

- Contradictions created by being member to the World Trade Organization (WTO) and to regional integrations."

Likewise, Irnazarov and Salmanov (2011: 1) studied the perceptions of economic actors in Kazakhstan and Uzbekistan about regional integration and concluded that "the majority of economic actors see little or no use in integrating with their neighbors." Irnazarov and Salmanov (2011) linked this outcome to the lack of information and limited knowledge of each other. Furthermore, researchers believe that "the reluctance to cooperate" between the countries concerned is caused by "political, economic, cultural and psychological factors". On the other hand, Linn (2012: 100-101) analyzed the political obstacles to regional integration in Central Asia. Those impediments from within are summarized as following:

- Reluctance of Central Asian leaders to transfer some of the state sovereignty to supranational body;

- Competition within Central Asia "for control of resources, especially water and energy (Tajikistan, Kyrgyzstan and Uzbekistan);

- "Rivalry for supremacy in regional leadership (Kazakhstan and Uzbekistan)";

- Preferring "to operate in strict neutrality to the point of isolation" rather than integrating into the region" (Turkmenistan); 
- "Limited or poor accountability in public decision-making and policy, pervasive corruption, smuggling and drug trade."

Some of these problems, such as intra-regional struggle for water, rivalry for regional leadership and border disputes have been settled or minimized in post-Karimov regional order. There has been substantial progress in intergovernmental bilateral and regional cooperation since new Uzbek government announced its "zero problems with neighbors" foreign policy. However, this development lacks clear-cut regional integration strategy as CA countries have divergent foreign policy priorities.

\subsection{Regional Integration via Extra-Regional Major Powers}

Theoretical and practical development of regional integration is primarily divided into two categories: old and new regionalism (Hettne, 1993, 2005; Hurrel, 1995; Fawcett and Hurrell, 1995; Hettne, Inotai and Sunkel, 1999; Söderbaum, 2016). There are different other "waves", "phases", "typologies" and "generations" of regional integration as well (Bhagwati, 1993; Breslin, 2002; Costea and Langenhove, 2007; Shaw, Grant and Cornelissen, 2011). In one of the recent studies, Lombaerde and Söderbaum (2013) distinguished four periods of regional integration. These are:

- Classical Regional Integration (1945-1970) which refers primarily to European integration theories and practices (federalism, functionalism, neo-functionalism);

- Revisions of Classical Regional Integration (1970-1990) which highlights the challenging and questioning of classical regional integration theories by mainly intergovernmentalism, partly neo-realism and neo-liberalism;

- The New Regionalism (1990-2000) which "draws attention to the different world order context shaping regionalism in the 1990s, and pinpoint..."new" features of regionalism." It also refers to "new" contents (including a series of non-trade issues), new theories and approaches" that influenced regionalism (liberal intergovernmentalism, constructivism, neo-classical realism theories and cross-disciplinary approaches);

- Comparative Regionalism (2000-2010) which refers to comparative analyses between European and non-European regional integration processes and the new theoretical and methodological developments (externality theory, contracting theory, regional security complex, comparative methodological approaches etc.).

These academic approaches considered and evaluated different aspects and forms of regional integration around the world. However, the comprehensive analysis of the impact of external actors on regional integration is limited in scope and quality in the literature since there has been no successful example of exogenous (outside-in) regional integration yet. Nevertheless, some early works evaluated the role of external factors hypothetically while recent ones scrutinized the impact of regional dominant states and external powers on evolving regional integration processes based on the isolated case studies in America, Africa and Asia (Denha, 1969; Haas, 1970; Cochrane and Sloan, 1973; Mytelka, 1973; Muttli, 1999; Bilal, 2013; Plummer, 2017; Muntschick, 2013, 2018).

However, based on the limited availability of theoretical and empirical studies, it is possible to suggest that great powers (states or organizations) within or outside the particular region 
exert positive, negative and mixed effects on regional integration. In other words, great power may foster, impede or complicate regional integration processes.

Regarding positive effects, an extra-regional power supports regional integration if it serves for its strategic goals. An example of a positive effect of a great power on economic integration is United States' support for the EU and ASEAN (Beloff, 1963; Beugel, 1966; Alagappa, 1989; Tong, 2000; Plummer, 2017). In addition, Central American Common Market (CACM) in Latin America, the Customs and Economic Union of Central Africa (UDEAC), and West African Economic and Monetary Union (UEMOA) in Africa "survived largely as a result of support from exogenous actors" like USA, France and EU (Haas, 1970:620; Cochrane and Sloan, 1973; Mytelka, 1973; Bilal, 2013). EU supported the Southern Common Market (MERCOSUR) from the beginning up until now in the form of "international recognition, 1992 and 1995 agreements, financial support to regional programs and institutions such as the Secretariat and the Parliament, support in internal crises" (Hoffmann and Kfuri, 2007: 21). The EU also played critical role in the success story of the bloc.

On the other hand, when a regional integration effort contradicts with or undermines the interests of extra-regional great power, the latter may try to hinder it through politicoeconomic instruments. In this sense, "a hegemonic extra-regional actor can use his payoff capacity (among others) to undermine the will (of regional countries) to integrate, as has been alleged of the United States in dealings with Latin American Free Trade Association (LAFTA)" and, to a certain extent, MERCOSUR in Latin America (Denha, 1969; Haas, 1970: 620; Hoffmann and Kfuri, 2007: 20-21.). Washington did not support MERCOSUR as an institution since the bloc aligned with the EU to compete economically with and geopolitically stand against the US (Hoffmann and Kfuri, 2007: 21).

Extra-regional great power may complicate regional integration due to a number of reasons. Firstly, if the previously supported weaker regional union (e.g., European Economic Community) has become economic rival force (e.g., European Union), then the external power (in this case, the US) would respond negatively, resulting in mixed impacts on the former. Recent economic disputes in US-EU relations are one of the examples of this situation. Secondly, the structural problems of underdeveloped countries within a regional integration scheme create serious issues due to these dependencies on the extra-regional great power. On the one hand, the EU played as an "integration model", major external donor and main trade partner for Southern African Development Community (SADC), Southern African Customs Union (SACU), Economic Community of West African States (ECOWAS), UEMOA and other regional economic communities (REC) in Africa. On the other hand, because of African country's structural problems, the EU has had a deconstructive impact on these RECs, which may lead to their further fragmentation (Marinov, 2013; Muntschick, 2013).

In all these cases, extra-regional powers prioritized their interests, which end up with serious asymmetries in their relations with RECs. For instance, the US supported the integration of European (EEC), Central American (CACM), African (UDEAC, UEMOA) and Asian (ASEAN) RECs as part of its struggle against Soviet Union and for maintaining its hegemonic dominance over these regions. Similarly, France funded UDEAC and UEMOA in order to advance its geostrategic interests in its former colonies. Equally, EU aided SADS, SACU, UEMOA, ECOWAS and MERCOSUR for spreading its regional integration "model" and competing with regional and global rival economic actors, such as US and China. 
Nevertheless, scholars like Mattli $(1999,2012: 789)$, believe that "the presence of a dominant state to be necessary to overcome regional coordination dilemmas and resolve distributional" plus other obstacles of regional integration. As such, the regional power or dominant country that will assume the role of catalyst, paymaster and coordinator in the integration process (like Germany in the EU, the US in NAFTA and CAFTA-DR, South Africa in SADC and Brazil in MERCOSUR) must come out of the region itself. Similarly, Muntschick (2018: 46) argues that due to structural reasons, regional great powers act as hegemonic actors, and play important roles in emergence, design, and effectiveness of regionalism.

However, in the case of Central Asia, it is not possibletotalkaboutan intra-regional dominant power to bring about a successful economic integration. Although Kazakhstan is the most successful country in the region in terms of economic and strategic position, its regional influence (due to its weaker military strength) is not strong. On the other hand, Uzbekistan, though militarilystronger than Kazakhstan, iseconomicallyand politicallyincapable of being a force for regional integration. Consequently, some authors present extra-regional great powers as alternative catalyzers in this process. For instance, Libman and Vinokurov (2011: 486) claim that for a number of reasons regional integration in CA is almost impossible without the involvement of former Soviet republics, primarily Russia. Qoraboyev (2010: 225) argues that there is "the shift from Central Asian regional integration to the Eurasian regional integration" under the leadership of Russia, which may lead to "the emergence of new regional system." Similarly, other scholars, considering hard, soft power capabilities and proposed initiatives of Russia, China and the US, hint at the possibility and prospects of regional integration or regionalism via major powers in Central Asia (Tang, 2000; Schirm, 2002; Buzan and Wæver, 2003; Wu and Chen, 2004; Starr, 2005a, 2005b; Rumer, Trenin, and Zhao, 2007; Kavalski, 2010; Zhengyuan, 2010, Linn, 2012).

However, exogenous factors are unique in Central Asian case. Regional integration initiatives that we have analyzed above shortly are predominantly indigenous proposals in essence. In other words, these RECs established from within, then developed, survived, stalled, hindered or complicated as a result of the support, opposition or mixed reaction of extra-regional major powers. On the contrary, regional integration in CA is proposed by extra-regional great powers. It is an outside-in regionalism. For this reason we offer to call it as Great Power Regionalism in which main initiators and driving forces of regional integration are not regional dominant catalyst states within the region or non-state actors, but extra-regional great powers. ${ }^{2}$ This is a new phenomenon in regionalism in the

2 We intend to develop a theoretical framework around this concept to explain particular aspects of great power-imposed extra-regional integration processes in Central Asia thoroughly in another article. This will be a new conceptual framework in regionalism literature. However, we should mention that similar or a near expression of the concept of "Great Power Regionalism" has been used by several authors in different ways and forms. For instance, Rosman applies a phrase of "Great-Power Regionalism" to evaluate regionalism in Northeast Asia. Similarly, Baogang refers to different regionalism initiatives in Asia as "Great Power-Led Regionalism". Zhengyuan uses the phrase of "Great Power-Sponsored Regionalism" in his comparative analysis of various approaches to regionalism in Central Asia. However, these authors did not give a specific conceptual meaning or provide an explanation for those phrases. See: Rozman, G. (2004). Northeast Asia's stunted regionalism: Bilateral distrust in the shadow of globalization. Cambridge: Cambridge University Press, p.34; Baogang, H. (2017). Contested ideas of regionalism in Asia, New York: Routledge, p.17; Zhengyuan, X. (2010). In the shadow of great powers: A comparative study of various approaches to regionalism in Central Asia. Connections, 9(4), p.37. 
sense that such an extra-regional integration processes have not been registered in any other parts of the world since the beginning of the study of regional integration. That is why existing theories may be insufficient, and further research is necessary in order to develop new theoretical framework. As mentioned, the main objective of this paper is to analyze the role and influence of great powers on regional integration processes. For that matter EAEU, BRI and NSR are comparatively analyzed.

\section{RUSSIAN EURASIAN ECONOMIC UNION PROJECT}

After decades of humiliation and subordination to other great powers like the US in international arena, President Putin needed to formulate a new defensive and offensive power bloc in and around Russia. That bloc could restore Russia's power and hegemony in the region and also enable a firm stand against Western political-economic expansion, terrorist movements in the South and the rise of China from the East. Thus, Putin initiated his grand project, the EAEU, in October, 2011. Putin's article, "A New Integration Project for Eurasia: A Future That is Born Today," proposed a regional integration model for Russia, Kazakhstan, Belarus and other former-Soviet republics. ${ }^{3}$

Putin proposed a new vision of regional economic and security cooperation of the Eurasian countries. He also proposed the creation of new political-economic bloc, known as the Eurasian Union which, in his view, would enable its member states to "become leaders of global growth and civilized progress, and to attain success and prosperity" (Putin, 2011).

Putin noted that the new Union would be built on the experiences of previous integration projects in post-Soviet space. According to Putin, EAEU is not about "recreating the Soviet Union in one form or another, but "proposal" to initiate "a powerful supranational union", which can become one of the power "poles" of the world and play a key role of "an effective link" between Europe and Asia. Secondly, Putin stated that EAEU will serve "as a center for further integration process" of former Soviet republics. Thus, he reiterates that EAEU is "an open project" and other countries can freely join in it, making independent decision according to the needs and "Iong-term national interest" (Putin, 2011). Putin's proposal could be described as "second integrative response" to the EU and the US-led western military-political-economic alliance since Russia's previous quests for cooperation and economic integration with the latter were rejected or failed categorically. ${ }^{4}$

Kazakhstan and Belarus welcomed Putin's EAEU project. On 18 November 2011, the presidents of the Russia, Kazakhstan and Belarus signed the treaties establishing a commission supervising the economic integration of the three post-Soviet countries (Novikova, 2011). Thus, within the territory of EurAsEC (2000) and Customs Union (CU) (2010), the Single Economic Space was established on 1 January 2012. Based on the treaties,

3 Initially Putin proposed it as Eurasian Union but during the negotiations, the project was renamed as Eurasian Economic Union. One has to note that Putin is not a sole "inventor" of creation of EAEU. The idea of creation of single economic community on the basis of post-Soviet states are taken from the proposal of forming "Eurasian Union" offered by the President of Kazakhstan, Nursultan Nazarbayev in 1994.

4 "Second integrative response", according to Mattli (1999: 14), occurs "if an outsider is rejected, or knows it is likely to be rejected if it were to apply, or is unwilling to accept the terms of membership in a given group." In this case an outsider (Russia) may form its own counter-union against or in response to the threatening rival union (EU or US-led NATO). 
the Eurasian Economic Union was formally created on 1 January 2015 between Russia, Belarus and Kazakhstan. In 2015 Armenia and Kyrgyzstan joined the Union. While Tajikistan is still considering joining the EAEU, Turkmenistan remains neutral. During premembership negotiations with Belarus, Kazakhstan, Armenia and Kyrgyzstan, Moscow employed economic, military, political and even cultural instruments (e.g., military bases, security and economic assistance, diaspora, labor migration, cultural cooperation and Russian media-dominated information space) to exert influence on the applicants.

Uzbekistan, during Karimov's rule, strongly rejected Putin's project as official Tashkent did not want "to turn back the history" to old Soviet dictatorship or to be "entrapped" into political-military unions that can deprive the country from independent decision making power (Trilling, 2011). Even Nazarbayev ("an inventor of the idea of Eurasian Union), who wholeheartedly welcomed and supported Putin's EAEU project, has lately, especially after the crisis in Ukraine and annexation of Crimea by Russia, followed the former Uzbek president Karimov's suit and became critical of and expressed concerns about Putin's attempts to give the EAEU more "political attributes." He said that "EAEU should be only about an economic union; any political attributes must be excluded from the project" (BBC Uzbek, 2013). Kazakhstan and Belarus also rejected the idea of creating "Supranational Eurasian Parliament" initiative, hesitating to give up their sovereignty to a supranational body, which would deprive their political elite of bargaining power and enable Russia to take full control of political and decision-making process (Tengri News, 2013).

In contrast with its establishing Treaty and Putin's proposal, EAEU could not be a rulebased Union since its creation in 2015. It has been a kind of individual deal-based or "power-based rather than rule-based" regional integration organization (Dragneva and Wolczuk, 2017: 7). For example, weak EAEU institutions could not reinforce existing dispute-solution mechanisms and related binding rules during economic disputes between its members: Russia-Belarus, Russia-Kazakhstan and Kazakhstan-Kyrgyzstan. Instead, power politics and bilateral deals made by state leaders played determining role in the dispute-solution negotiations (Roberts and Moshes, 2016). On the other hand, "Russia has also refused to be constrained" by the Union institutions and did not abide by rules for several occasions (Dragneva and Wolczuk, 2017: 2). Lack of commitment to deep economic integration, weak institutional structure, Russia's dominant position and ongoing economic crises slowed down the further integration and expansion of the EAEU in the post-Soviet space, including CA.

However, some security factors, in this case the security situation in Afghanistan, may benefit Russia in the realization of EAEU project. For example, Kyrgyz and Tajik armies, despite Russian military presence and assistance ${ }^{5}$, are still very week to stand against possible threats coming from Afghanistan (Lukin, 2007 May 21; Sputnik, 2013). Both countries are the members of Collective Security Treaty Organization (CSTO), but CSTO's effectiveness in combating against radical militants yet remains to be seen. Overall, Kazakhstan, Uzbekistan, Tajikistan and Kyrgyzstan are not in a position to effectively

5 Russia has military air base in Manas, Kyrgyzstan and made a deal with Kyrgyz government to deliver military aid-the arms worth up to 1.4 billion dollars and Tajikistan have 201-Russian division with up to 7000 soldiers on its soil. 
provide security and stability for the region. Turkmenistan considers itself as "neutral" country and assumes that its "status of neutrality" will protect it from threats of radical militants. However, in case of more acute threats, Turkmenistan has no choice other than relying on Russian help. Thus, the Central Asian secular governments feel threatened by the growing influence of radical insurgents from Afghanistan, and may easily prefer Russia as a guarantee of regional stability.

For Putin, EAEU project is a way to prevent or, at least, decrease growing Chinese influence in CA. Russia still controls the majority of CA's energy and other export routes, but its relative economic dominance in the region is fading. Even the presence of huge number of Central Asian migrants in Russia could not provide necessary options for Moscow to influence the increasing "friendship" between China and CA countries directly. In this regards, the EAEU project reflects Russia's plans to counter the growing Chinese and American presence in CA.

\section{CHINESE SILK ROAD ECONOMIC BELT PROJECT}

Silk Road Economic Belt (SREB) was first initiated in Kazakhstan in 2013 by the visiting Chinese President, Xi Jinping. The project has two lines, one is land-based Silk Road Economic Belt and the other is seagoing " $21^{\text {st }}$ Century Maritime Silk Road." ${ }^{\text {The }}$ project officially intends to rejuvenate the ancient Silk Road and boost the economic cooperation between Asia, Europe and Africa. Land-based component of the project starts from China and will go through Central Asian, Caucasus, Middle East, Turkey, Russia, and ends in Europe. Oceangoing line of the project even extends to Africa before reaching Europe. Later on these two sections were merged and branded as "Belt and Road Initiative" (BRI). ${ }^{7}$ However, this paper examines Central Asian section of BRI, the SERB.

The SREB in particular, BRI in general is multitrillion dollar project that "consists of connecting new and existing networks of roads, railways, tunnels, bridges, oil and gas pipelines, optical networks, industrial parks, logistical centers and seaports, rearranging the traditional relationships between the production centers, markets and sources of raw materials" of vast Eurasian-African region and beyond (Eszterhai, 2017; Swanström and Nyrén, 2017: 1). In other words, China is building, reconstructing, connecting, and rearranging the whole economic infrastructure and trade flow of the Asia, Europe and Africa. For that reason, some researches labeled BRI as "Chinese Marshal Plan", comparing it with US Marshal Plan that restored war-torn Europe and helped to build post-war world order under the leadership of the US (Shen and Chan, 2018).

6 This Chinese grand strategy is being developed carefully and gradually, taking into account the delicate and critical geopolitical balances and developments around the world. For that matter, the official name of the project was merged and changed as "One Belt, One Road", later on as "Belt and Road Initiative" or just "Belt and Road". China is also intentionally "forbidden to translate the (Chinese) phrase ?]? (changyi) in Chinese official document into other languages as "strategy", "program", "project" or "agenda". Instead, the phrase is translated as "initiative". By doing so, Chinese government intends to present "Belt and Road" as geopolitics-free, joint efforts-based initiative rather than a grand geopolitical strategy. See for more details: Stec, G. (2018, February). China's Belt and Road Initiative is neither a strategy, nor a vision. It is a process. European Institute for Asian Studies. Retrieved from http://www.eias.org/wp-content/uploads/2016/03/ EU Asia at a Glance Stec BRI 2018-1.pdf (Accessed: 2018, September 12).

7 BRI encompasses more than 65 countries, "if fully realized, would bring together over $70 \%$ of the world's population, which accounts for about $55 \%$ of global GDP and has about $75 \%$ of discovered energy reserves" (He, 2015; Wolff, 2016; Svetlicinii, 2018). 
Cheng (2015: 285-286) distinguishes three characteristics of land-based SREB": "A network for Eurasian countries to cooperate with and benefit each other"; "it will not be a formal system arrangement like EU or EAEU for foreseeable future"; "it is not a geopolitical plan dominated solely by China", it requires the joint efforts of Eurasian countries.

Based on the will of participating countries, SREB includes all forms of economic, social and cultural cooperation. Its goal is to create "Five links" among participating countries, which "refer to linkages in policies, infrastructure, trade, finance and people" (The Fung Business Intelligence Centre, 2015: 6). It is claimed that it would exclude politics and value-driven issues. Unlike the Russian and American initiatives, the Chinese project doesn't dictate the rules of integration. It has no coercive instruments and is based solely on mutual economic cooperation. It is supposed to be an open process for all interested countries. In fact, China seems to be determined to keep the US and Japan out of the project. Officially, the project will be built on "five principles of peaceful coexistence: mutual respect for each other's sovereignty and territorial integrity, mutual non-aggression, mutual non-interference in each other's internal affairs, equality and mutual benefit, and peaceful coexistence" (Ministry of Foreign Affairs of P.R.C., 2015: 6). According to Xinhua (2014), China is going to build a world of "win-win" based on "mutual respect and mutual trust."

In the light of SREB project China is swiftly enhancing its economic and diplomatic relations with CA. Because of Chinese massive credits, investment (in energy and infrastructure for hundreds of projects) and trade agreements, one can argue that CA "became the economic backyard" of China.

China is jointly financing and building road and railroad connection from its western border to Central Asia. In 2014 China announced that it would create $\$ 40$ billion fund to materialize the SREB project (Page, 2014). Besides, with the opening of Central AsiaChina gas pipeline in 2009 and starting of gas export from Turkmenistan and Uzbekistan to China a new phase began in the history of the region. The pipeline can export up to 40 billion cubic meters of Turkmen and Uzbek (currently 10 billion cubic meters) gas to China every year. In 2011 China agreed to build the pipeline's third strand allowing Uzbekistan exporting around 18 billion cubic meters of gas to China by 2014 and increasing it to about 25 billion in 2016. Turkmenistan has already become China's largest foreign supplier of natural gas as China started exploiting world's second-biggest gas field, Galkynysh. It will help triple Chinese imports from the country (Xinhua, 2013; China National Petroleum Corporation, 2014).

By 2010, China surpassed Russia as Kazakhstan's top economic partner with the overall trade turnover of $\$ 20$ billion. China's total trade volume with CA reached nearly $\$ 50$ billion by 2013. In 2013, China announced that it will invest $\$ 30$ billion in Kazakhstan that includes a stake in Kashagan, the world's largest oil discovery in recent decades. China also promised $\$ 64$ billion infrastructure investment for CA. Currently China is carrying out $\$ 26$ billion worth of infrastructure projects in Kazakhstan. China has secured several agreements with Uzbek government worth up to $\$ 15$ billion in oil, gas and uranium deals. It also provided a \$3 billion financial aid package for Kyrgyzstan. Finally, China and Uzbekistan signed more than 100 agreements worth of \$23 billion in 2017 (Sarsenbaeva, 2013; Standish, 2014; He, 2015; Muzalevsky, 2016; Xidirov, 2017). 
In sum, China managed to strengthen its energy, economic and diplomatic ties with Central Asian republics, namely via the multibillion dollar credits, investments, construction of several oil and gas pipelines, railroads and highways (Voloshin, 2012; Sarsenbaeva, 2013). China also promised $\$ 50$ billion to its Asian Infrastructure Investment Bank for which 57 countries (including all CA countries, except Turkmenistan) applied to join as founding shareholders (Economist, 2015; Huang, 2015).

China has also established economic and political linkage between its BRI and EAEU. In 2015, Russia and China issued a joint statement on "integrating the integration" projects. The following cooperation areas were determined between EAEU and BRI: "(1) trade and investment facilitation; (2) joint investment projects; (3) enhancing infrastructure connectivity; (4) free trade agreement between the EAEU and China in a long-term perspective38; (5) promotion of SMEs; (6) facilitation of payments in national currencies; (7) cooperation within the Asian Infrastructure Investment Bank, Silk Road Fund, SCO Interbank Consortium; (8) global trade and investment governance." (Svetlicinii, 2018: 15)

There are numbers of risks that may challenge Chinese SREB project in CA. Deterioration of regional security, sudden state of emergency, economic crisis, and shift from authoritarianism to democracy, mismanagement and misconduct on the side of Chinese firms and growing anti-Chinese sentiments among others may obstruct further expansion of Chinese influence (Swanström and Nyrén, 2017).

Analyzing Beijing's attitude towards some of the BRI countries, US Department of Defense (US DoD) highlighted that China might have strategic hidden goals behind BRI. US DoD report alleged that China is using BRI to develop strong economic relations with other countries, shape their interests in harmony with its own, and "deter confrontation or criticism of China's approach to sensitive issues." The report predicts that "some countries participating in the BRI can develop economic dependence on China's capital" (US Department of Defense, 2018: 111). Sequentially, the report says, China may use this economic advantage to reach its geostrategic interests. ${ }^{8}$ Overall China's behavior with regard to debtor countries may also affect the intended outcome of BRI.

These claims are backed up by some serious cases on the ground. For instance, as Sri Lanka could not "service a \$8 billion loan at 6 percent interest that was used to finance the construction of the Hambantota Port", it had to hand over the port and "15,000 acres of land around it for 99 years" to China as "a debt-for-equity swap" in 2017 (Hurley, Morris and Portelance, 2018: 20; Abi-Habib, 2018). Similar agreements were made with economically struggling Greece's Piraeus and Australia's Darwin ports (US Department of Defense, 2018: 50). Concerned that economic overdependence on China could turn into a new form of colonialism, Malaysia's new Prime Minister, Mahathir Muham-

8 The report also stresses that "some BRI investments could create potential military advantages for China" in accessing "selected foreign ports and pre-position necessary logistical support to sustain" its maritime forces in order "to protect Chinese growing interests" in and around the Indian Ocean, the Mediterranean, the Atlantic Ocean and beyond. 
mad, halted $\$ 22$ billion worth of China-financed projects in his country (Beech, 2018). ${ }^{9}$ The case of Sri Lanka and Malaysia highlighted the misconduct on the side of Chinese government that it allegedly used bribery and other illegal methods to win deals in foreign countries for its hidden agenda.

Similarly, the weakest and poorest countries of CA, Tajikistan and Kyrgyzstan, faced with Chinese debt distress after receiving too much loans. By the end of 2016, Kyrgyz debt to China reached $\$ 1.5$ billion, $40 \%$ of the country's total external debt. Kyrgyzstan was also indebted $\$ 4.5$ billion to China within BRI project investments at that time which is equal to nearly $71 \%$ of its total external debt. Tajikistan's debt to China amounted for $\$ 1.2$ billion, 53 percent of its total external debt. Additionally, its "BRI lending pipeline" debt was $\$ 2.5$ billion or almost $80 \%$ of its overall external debt in 2016 . Both countries are two of the eight most vulnerably countries assessed "by the IMF and World Bank to have a "high risk" to the debt distress of BRI." China allegedly offered to cancel an undisclosed sum of Tajikistan's debt in return for nearly 1,158 square kilometers of disputed borderland in 2011. Tajik government stated that it only provided 5.5 percent of the land that China demanded in exchange for its debt. (Hurley, Morris and Portelance, 2018: 11, 19, 20, 28; Fernholz, 2018). Chinese government also approached to Kyrgyz authorities in a bid to acquire strategic energy and infrastructure deals using its alluring economic tools.

Because of Chinese loans and credits, all CA countries are supporting China's position on bilateral, regional, multilateral and global level. For instance, CA countries are backing up Beijing's "One-China" policy, land claims and international disputes, such as its claim on Taiwan and South China See. Neither CA governments nor their mainstream media mention or criticize China's repressive policies and human rights violations against Uighurs and Tibetans in the western parts of the country. On the contrary, CA countries are firmly supporting China's double standard fight against so-called "three evil forces", namely terrorism, separatism and extremism. State-media in CA always praises the Chinese model of development and frequently broadcasts Chinese serials especially at prime time (Berkofsky, 2012; Voloshin, 2017; UzA, 2017; Xinhua, 2017; Chen and Fazilov, 2018; Hashimova, 2018).

Some argue that China is deliberately giving out such high amount of loans and credits to especially those weak countries that are unable to pay back, in order to achieve its strategic goals. This tricky tactic is being called as "Chinese debt-trap diplomacy" (The Economist, 2018; Diwakar, 2018; Parker and Chefitz, 2018). One of the famous China experts Pomfret (2018) even described "China's debt traps around the world" as "a trademark of its imperialist ambitions." Beijing's grand strategy is also assessed as "China's search for new world order" in light of declining US supremacy (Hodzi and Chen, 2017).

For China, the economic expansion into CA (including its billions of dollars loans to the countries in this region) is the key to impede growing US and Russian influence in the re-

9 It is alleged that former Prime Minister Najib Razak, to save indebted economy and remain in power, signed multibillion-dollar unnecessary agreements that are against the interests of his country with Chinese companies in exchange for bribe and political support from Beijing. China is also accused of using Malaysia's economic difficulties as an opportunity to strengthen its position in the Malacca Strait, which links the South China Sea to the Indian Ocean and has strategic importance in international trade. 
gion. Moreover, the regional governments also seem to prefer to maintain strong economic ties with China, as the latter does not get involved into human rights and democracy-related disputes with CA countries. Thus, promised benefits of Russian and American initiatives will unlikely encourage CA countries to turn their back to vast economic and trade opportunities coming from China. China's entrance into the oil and gas markets of CA region will likely make the relationship between the former and the latter closer. This relationship will also bring another dimension into the security and development of China. With the security situation worsening in Afghanistan and, to some extent, alongside China's south-western borders, Beijing's main priorities will be to secure oil and gas pipelines, access more resources and eliminate threats to its economic interests in and around the region by engaging with CA countries.

\section{AMERICAN NEW SILK ROAD PROJECT}

The US's "New Silk Road" project was initiated in 2011. However, it is not a new plan. Even before the invasion of Afghanistan in 2001, the US was working on and offering some regional integration guidance to the CA region. In 1999, the US announced "Silk Road Strategy Act" (SRSA) and one of its goals was to "contribute for the regional economic integration" in CA (Silk Road Strategy Act, 1999). Later on, the increasing Russian and Chinese influence in CA and new security situation in Afghanistan created a need for US government to develop a new regional approach and clear long-term foreign-security policy goals for post-war Afghanistan and for whole region. Thus, the US government adopted "Greater Central Asia Project" (GCAP) in 2005. GCAP was first proposed by the Chairman of Central Asia-Caucasus Institute \& Silk Road Studies Program, S. Frederick Starr, and the US government accepted the concept. According to Starr, GCAP would create a regional framework for Central Asian states and Afghanistan, in which the US should take the main lead (Starr, 2005a). In addition, Starr (2005a:17) notes that through the GCAP partnership, the US would become "a midwife for the birth of this new region." Through the GCAP, the US intended to become the main "provider" and "promoter" of peace, security, economic cooperation and regional integration in CA.

It should be noted that the GCAP project gives main importance to Afghanistan as the key player of the Greater Central Asia. According to the project, "systematic development of regional trade and continental transport" will help Afghanistan and its neighbors to escape from dependence on Russia and China, to deliver their agricultural products and mineral resources to world markets, to create millions of new jobs, "to move from the economic periphery to the very center" of a new Greater Central Asia. Thus, it will increase "economic progress and social stability" of Afghanistan and other CA countries and "remove" Afghan threat "once and for all" (Starr, 2005a:14).

The US's New Silk Road (NSR) project is an updated and extended version of GCAP and a kind of counter move to Russia's EAEU project and China's economic expansion in CA (see Table 1 below). Former US Secretary of State Hillary Clinton openly criticized Putin's proposal as "a move to re-Sovietize the region" and vowed to "try to figure out effective ways to slow down or prevent" its actualization (Clover, 2012). Besides, taking into account the realities of post-NATO Afghanistan and Central Asia, the NSR project emphasizes on economic and security cooperation using existing and proposed USbacked mechanisms and projects, such as Central Asia Regional Economic Cooperation 
(CAREC), Turkmenistan-Afghanistan-Pakistan and India gas pipeline (TAPI), and Central Asia-South Asia Electricity Transmission and Trade Project (CASA-1000) (Standish, 2014). NSR project intends to "integrate Afghanistan to the economies of Central and South Asia to promote prosperity and stability across the region. The initiative focuses specifically on building a regional energy market, facilitating trade and transport, easing customs and border procedures, and promoting people-to-people ties, especially among businesspersons and entrepreneurs" under the leadership of USA ( Bills, 2014).

Interestingly, like the GCAP, New Silk Road project assumes to bring huge benefit, "based on local sovereignties rather than conquest or domination", not only for the Greater Central Asia, but also for Russia and China as Afghanistan becomes a "window to the sea" for CA. It is expected that NSR will help Russia to develop "vast and economically struggling parts of Russian Siberia and the Urals", and benefit China's effort to foster security and economic growth in Xinjiang Uyghur Autonomous Region (Starr, 2005a: 14; Weitz, 2015).

In sum, unlike Russia and China, the US did not persistently push for the realization of its project. Considering its souring international image, especially in CA and Afghanistan, Washington preferred to facilitate and indirectly promote NSR related projects from behind.

\section{Table 1. The Three Major Extra-Regional Integration Projects in Central Asia}

\begin{tabular}{|c|c|c|c|}
\hline & $\begin{array}{l}\text { Eurasian Economic } \\
\text { Union (Russia) }\end{array}$ & $\begin{array}{l}\text { New Silk Road } \\
\text { (USA) }\end{array}$ & $\begin{array}{l}\text { Silk Road Economic } \\
\text { Belt (China) }\end{array}$ \\
\hline $\begin{array}{l}\text { Time of the } \\
\text { latest version }\end{array}$ & 2011 & 2011 & 2013 \\
\hline $\begin{array}{l}\text { Predicted } \\
\text { implementation }\end{array}$ & 2015 & $\begin{array}{l}2014 \text { (currently put } \\
\text { on hold) }\end{array}$ & n/a (continuing) \\
\hline Starting point & $\begin{array}{l}1995 \text { - CU Protocol; } \\
2000 \text { - EurAsEC; } \\
2010 \text { - CU; } 2012 \text { - } \\
\text { SES; } 2015 \text { - EAEU }\end{array}$ & $\begin{array}{l}1999 \text { - SRSA; } 2005 \text { - } \\
\text { GCAP; } 2011 \text { - NSR }\end{array}$ & $\begin{array}{l}1994 \text { - Silk Road } \\
\text { proposal; } 2013 \text { - } \\
\text { SREB }\end{array}$ \\
\hline Official goals & $\begin{array}{l}\text { "To upgrade, raise } \\
\text { the competitive- } \\
\text { ness of and cooper- } \\
\text { ation between the } \\
\text { national economies, } \\
\text { and to promote } \\
\text { stable development } \\
\text { in order to raise the } \\
\text { living standards of } \\
\text { the nations of the } \\
\text { Member States."; To } \\
\text { enable its Member } \\
\text { States to "become } \\
\text { leaders of global } \\
\text { growth and civilized } \\
\text { progress, and to } \\
\text { attain success and } \\
\text { prosperity." }\end{array}$ & $\begin{array}{l}\text { To "integrate Af- } \\
\text { ghanistan to the } \\
\text { economies of Cen- } \\
\text { tral and South Asia } \\
\text { to promote pros- } \\
\text { perity and stability } \\
\text { across the region; } \\
\text { To build a regional } \\
\text { energy market, } \\
\text { facilitate trade and } \\
\text { transport, ease cus- } \\
\text { toms and border } \\
\text { procedures, and } \\
\text { promote people- } \\
\text { to-people ties, } \\
\text { especially among } \\
\text { businesspersons." }\end{array}$ & $\begin{array}{l}\text { To create "Five } \\
\text { links", among the } \\
\text { participating coun- } \\
\text { tries, which "refer } \\
\text { to linkages in poli- } \\
\text { cies, infrastructure, } \\
\text { trade, finance and } \\
\text { people"; "To build } \\
\text { a network for Eur- } \\
\text { asian countries to } \\
\text { cooperate with and } \\
\text { benefit each other." }\end{array}$ \\
\hline
\end{tabular}




\begin{tabular}{|c|c|c|c|}
\hline $\begin{array}{l}\text { Perceived } \\
\text { strategic } \\
\text { objectives }\end{array}$ & $\begin{array}{l}\text { To form new defen- } \\
\text { sive and offensive } \\
\text { power bloc in and } \\
\text { around Russia } \\
\text { which is expected } \\
\text { to enable Moscow } \\
\text { not only to restore } \\
\text { its great power sta- } \\
\text { tus and hegemony } \\
\text { in the region, but } \\
\text { also to stand firmly } \\
\text { against Western } \\
\text { political-economic } \\
\text { expansion, terrorist } \\
\text { movements in the } \\
\text { South and the rise } \\
\text { of China from the } \\
\text { East. }\end{array}$ & $\begin{array}{l}\text { To contain Russia, } \\
\text { Iran and China; } \\
\text { reshape Central } \\
\text { and South Asian } \\
\text { geopolitical and } \\
\text { geo-economic land- } \\
\text { scape; maintain } \\
\text { hegemony as much } \\
\text { as possible. }\end{array}$ & $\begin{array}{l}\text { To hinder US and } \\
\text { Russian influence } \\
\text { in CA; Secure and } \\
\text { maintain oil and } \\
\text { gas pipelines and } \\
\text { eliminate the } \\
\text { threats to its eco- } \\
\text { nomic interests } \\
\text { in the region by } \\
\text { engaging with CA; } \\
\text { Maintain the sup- } \\
\text { port of CA coun- } \\
\text { tries in its struggle } \\
\text { against "three evil } \\
\text { forces" of terror- } \\
\text { ism, extremism } \\
\text { and separatism in } \\
\text { Xinjiang Uyghur } \\
\text { region. }\end{array}$ \\
\hline $\begin{array}{l}\text { Policy } \\
\text { instruments }\end{array}$ & $\begin{array}{l}\text { Military bases, } \\
\text { security and eco- } \\
\text { nomic instruments; } \\
\text { CSTO; EDB; Diaspo- } \\
\text { ra, Labor migration; } \\
\text { Cultural coopera- } \\
\text { tion; Russian domi- } \\
\text { nated information } \\
\text { space. }\end{array}$ & $\begin{array}{l}\text { Foreign aid, NATO's } \\
\text { partnership pro- } \\
\text { grams, CAREC, TAPI } \\
\text { gas pipeline and } \\
\text { CASA-1000 electric- } \\
\text { ity project. }\end{array}$ & $\begin{array}{l}\text { Financial aid, } \\
\text { investment and } \\
\text { credit; The Asian } \\
\text { Infrastructure } \\
\text { Investment Bank; } \\
\text { SCO; Pipelines; Rail } \\
\text { and road network; } \\
\text { Cultural coopera- } \\
\text { tion. }\end{array}$ \\
\hline Format & $\begin{array}{l}\text { Formal system } \\
\text { arrangement } \\
\text { (membership is } \\
\text { required). State- } \\
\text { led, deal-based } \\
\text { integration. }\end{array}$ & $\begin{array}{l}\text { Project-based } \\
\text { intergovernmental } \\
\text { integration system. }\end{array}$ & $\begin{array}{l}\text { Informal network, } \\
\text { based on bilateral } \\
\text { and multilateral } \\
\text { joint efforts. }\end{array}$ \\
\hline Accessibility & $\begin{array}{l}\text { Open to all former } \\
\text { Soviet and other } \\
\text { Eurasian countries } \\
\text { (except the US, } \\
\text { Western Europe, } \\
\text { and possibly } \\
\text { China). }\end{array}$ & $\begin{array}{l}\text { Open to all Central } \\
\text { Asian and South } \\
\text { Asian countries. Of- } \\
\text { ficially "welcomes" } \\
\text { Russian and Chi- } \\
\text { nese cooperation. }\end{array}$ & $\begin{array}{l}\text { Open to all CA and } \\
\text { Eurasian countries } \\
\text { (except the US, } \\
\text { Japan and possibly } \\
\text { South Korea). }\end{array}$ \\
\hline
\end{tabular}

However, it seems the case that Russia's "carrot and stick" policies, China's value-free economic supports and indirect pressure may have made CA states more interested in EAEU and SREB than in NSR (see Table 2). 
Table 2. Reaction of Central Asian Countries to Those Extra-Regional Integration Projects

\begin{tabular}{|c|c|c|c|}
\hline & EAEU (Russia) & NSR (USA) & SREB (China) \\
\hline Kazakhstan & $\begin{array}{l}\text { Full member, } \\
\text { Initially positive, } \\
\text { lately suspicious, } \\
\text { especially after the } \\
\text { crisis in Ukraine and } \\
\text { Russian annexation } \\
\text { of Crimea }\end{array}$ & $\begin{array}{l}\text { Partly cooperative } \\
\text { (CAREC) }\end{array}$ & $\begin{array}{l}\text { Positive and } \\
\text { cooperative on } \\
\text { mutually beneficial } \\
\text { issues }\end{array}$ \\
\hline Uzbekistan & $\begin{array}{l}\text { Initially negative } \\
\text { and critical, } \\
\text { however, it } \\
\text { cooperates with } \\
\text { EAEU within free- } \\
\text { trade zone of CIS } \\
\text { and other platforms }\end{array}$ & $\begin{array}{l}\text { Partly cooperative } \\
\text { (CAREC), partly } \\
\text { negative and critical } \\
\text { (CASA-1000), finally, } \\
\text { fully cooperative }\end{array}$ & $\begin{array}{l}\text { Positive and } \\
\text { cooperative on } \\
\text { mutually beneficial } \\
\text { issues }\end{array}$ \\
\hline Turkmenistan & $\begin{array}{l}\text { Formally neutral } \\
\text { (actually feels } \\
\text { threatened) }\end{array}$ & $\begin{array}{l}\text { Neutral, partly } \\
\text { cooperative } \\
\text { (CAREC,TAPI) }\end{array}$ & $\begin{array}{l}\text { Positive and } \\
\text { cooperative on } \\
\text { mutually beneficial } \\
\text { issues }\end{array}$ \\
\hline Kyrgyzstan & $\begin{array}{l}\text { Initially unclear, } \\
\text { lately positive and } \\
\text { now full member. }\end{array}$ & $\begin{array}{l}\text { Positive and actively } \\
\text { cooperative (CAREC, } \\
\text { CASA-1000) }\end{array}$ & $\begin{array}{l}\text { Positive and } \\
\text { cooperative on } \\
\text { mutually beneficial } \\
\text { issues }\end{array}$ \\
\hline Tajikistan & $\begin{array}{l}\text { Undecided } \\
\text { (evaluating cons } \\
\text { and pros of possible } \\
\text { membership) }\end{array}$ & $\begin{array}{l}\text { Positive and actively } \\
\text { cooperative (CAREC, } \\
\text { CASA-1000) }\end{array}$ & $\begin{array}{l}\text { Positive and } \\
\text { cooperative on } \\
\text { mutually beneficial } \\
\text { issues }\end{array}$ \\
\hline
\end{tabular}

Additionally, lack of clear strategy, financial allocation and political will on the side of US government slowed down the progress on the implementation of NSR projects. Finally, since Trump assumed the Presidency in the US he neglected NSR like other Obama legacies. Nevertheless, work on some of the NSR projects, such as TAPI and CASA-1000 are in progress while others are stagnated or suspended for unknown period of time. Whether Trump administration will revitalize NSR as part of its struggle against growing Russian and Chinese influence in Central Asia and South Asia or abandon it completely is a question that needs to be answered.

\section{CONCLUSION}

Despite being rich in natural recourses and agricultural products including gas, oil, precious metals, cotton, wheat among others, CA countries are geographically denied direct access to world markets through relatively cheap waterways. In search for the solution of the Soviet-made and natural (geographic) impediments on the way to economic development and better future, CA republics participated in post-Soviet integration projects. They even attempted a regional integration within CA through the formation 
of Central Asian Union, Central Asian Economic Union, Central Asian Cooperation Organization and Central Asian Economic Community.

However, for the variety of reasons both post-Soviet and regional level integration initiatives have proved ineffective practically. In other words, despite having common history, culture, similar language, political and economic structures CA countries continuously failed to make several attempts toward regional integration successful. Nevertheless, large numbers of scholarly community and even some political leaders like Nursultan Nazarbayev still believe that "there is no alternative to regional integration in Central Asia." It is widely accepted that without regional integration and cooperation in $\mathrm{CA}$, critical national and regional level issues like poverty, unemployment, uncontrolled mass labor migration, border and water disputes, growing nationalism and re-emerging security threats from Afghanistan cannot be tackled by a single country.

As indigenous regional integration initiatives failed to materialize, exogenous attempts to regional integration are on the rise in CA. In this sense, there is a new trend of regional integration via extra-regional great powers in the region. At present, Russia, China and the US are competing for influence over CA as the major outside players. Furthermore, those powers have been developing various "extra regional integration projects" for the last decades. We call this process Great Power Regionalism. The concept of Great Power Regionalism explains Russian, Chinese and American extra-regional integration initiatives in Central Asia. This concept may also be applied to shed some new light on similar Great Power Regionalism initiatives in different regions of the world. Great Power Regionalism implies that the great powers may resort to regionalism in order to increase their power, protect their interests, expand their sphere of influence and achieve other strategic goals in a rapidly globalizing and changing world. Thus, the Great Power Regionalism refers to the situation in which great power-imposed regionalism is used as a geopolitical means of influence by major powers. In this case, regional integration or regionalism is "a means to an end, not an end in itself." An example of a Great Power Regionalism strategy is EAEU, which is being used to institutionalize Russian presence and geopolitical influence in post-Soviet space.

In this regard, this paper also attempts to figure out what is the role and influence of great powers on regional integration processes. In these three projects, namely Chinese Silk Road Economic Belt, Russian Eurasian Economic Union and American New Silk Road project, one can see that great powers pursue different approach to regional integration. One can also observe the varying degree of influence of each major power on the regional integration in every approach. Sequentially, there is a regional reaction against the great power and its integration project, which may change the expected outcome as well as test the viability of these integration models.

In this respect, there are different, in some point, complicated responses from CA to China, Russia and the United States (see Table 2 above). While welcoming and participating in some components of above-mentioned projects, Central Asian countries are rejecting and trying to stay away from harmful "political" aspects of these integration models. For instance, Uzbekistan, during Karimov's rule, firmly rejected Russian EAEU and US-backed CASA-1000 that is one component of NSR. On the other hand, official Tashkent joined in some CAREC projects and a free-trade zone of Russia-led Commonwealth of Independent States. Tajikistan and Kyrgyzstan actively supported US-backed 
CASA-1000 project, on the contrary, Uzbekistan and Turkmenistan firmly stranded against it. With the beginning of post-Karimov era, Uzbekistan reviewed its previous position on CASA-1000 and decided to cooperate with the project participants. Besides, Tashkent also changed its critical attitude toward both EAEU and US-backed projects in and around Afghanistan positively.

According to the outcome of national and international polls, public opinion is in favor of EAEU in Central Asian countries, except Uzbekistan (Olimova, 2015:13; EDB, 2017:1920; Alisauskiene, 2017:60). Interestingly, public opinion is similar to that of government's throughout CA. Considering socio-political realities of CA, we assume that respondents may have considered their government's position first for the fear of possible reprisal or pressure and voted for the concerned projects accordingly.

However, according to Eurasian Development Bank survey public opinion in Uzbekistan was in support of Uzbekistan's possible membership to EAEU, contrary to the official position of Uzbek government (EDB, 2016:7). However, this support was declining year by year, especially after the annexation of Crimea by Russia in 2014. In a recent survey, most of the Uzbek respondents opposed possible membership of their country to the organization. ${ }^{10}$

On the other hand, Russia, China and US has also been criticizing each other's projects. Washington openly criticized EAEU as recreation of USSR and offered its NSR as rule-based regional cooperation and integration model. Two years after the official announcement of Russian and American project, China came up with its "politics and value free" initiative, namely SREB (BRI). In 2015, after Ukrainian crisis, isolated and economically depressed Russia decided to integrate EAEU with Chinese BRI in predetermined narrow economic domains. Afterward US also showed some interest in cooperation with Chinese BRI project in Afghanistan. All of these approaches could be evaluated as provisional tactic moves that would not affect the core strategic principles and visions of concerned projects.

Analyzing those three projects one could assume two major impacts of the great powers on regional integration and raise several important questions. First of all, does the major power bring regional actors together while promoting regional integration? Secondly, does it try to integrate itself into the region? What are the implications of the economic-military asymmetry for the region in question in the process of regional integration via major powers? In all cases the result seems to be as follows. Great power attempts to integrate the region into itself through asymmetrical methods and different means. These means may be political-military tools, economic factors or socio-cultural elements. All may coexist in one instrument of influence. In other words, first, great powers generally employ asymmetrical methods while trying to integrate the concerned region. These asymmetrical methods usually put the requests, the expectations and the objectives of the region as a secondary goal. Instead, the designs, plans and ambitions of the great powers are placed first.

10 We conducted online survey among the citizen of Uzbekistan at home and Uzbeks abroad in April 6 - June 30, 2018. More than six hundred people between the age of 16 and 72 with at least eight different professional, educational and social backgrounds, from all regions of Uzbekistan participated in the online survey. In contrast to Russia's EAEU, most of the Uzbek respondents supported China's SREB project. Supporters and opposers were almost in equal numbers in the case of the US' NSR project. 
Secondly, regional integration via extra regional great powers undermines the sovereignty and national security of the state. Especially, if there are deep political, economic, ideological and cultural differences between great power and the region, the independence and core national interests of the countries of the region will be undermined. Thirdly, it seems that major powers are reluctant to see truly regional integration within the region. That's why they use an old method - "divide and control" from time to time, even though they pretend to be supporting and promoting regional integration.

On the other hand, foreign policy-making paradigm of a great power, its position in international and regional system and the attitude of the region toward that great power may affect the outcome. Differences between Chinese, Russian and American approaches with regard to regional integration and divergent perceptions of these forces in CA will lead us to the verification or falsification of above-mentioned arguments in the future research.

However, at this stage the preliminary literature review and argumentation brings us to the following conclusion. There is no universally applicable, uniform model of regional integration formula promoted by the great powers. Three great powers' regional integration approaches are different from each other, but they all approach to a region asymmetrically. They prioritize their own interest and could discard regional actors' expectations. Additionally, these three projects are developed by, biased towards preserving the influence of great powers, and lack viable framework to bring both global and regional players into the path of lasting cooperation.

While the main motives of Russia, China, and United States in their promotion of regional integration projects in the CA may be based on their own geopolitical and/or economic interests (to integrate the region into itself, reap the economic benefits or make the region a strategic ally), one cannot rule out the socioeconomic benefits that the region may rip of one day if one or more of these projects become successful. However, the political cost of regional integration via extra-regional great powers seems to be higher than the pledged socioeconomic benefits it would bring. 


\section{REFERENCES:}

Abi-Habib, M. (2018, June 25). How China got Sri Lanka to cough up a port. The New York Times, Retrieved from https://www.nytimes.com/2018/06/25/world/asia/china-sri-lanka-port.html (Accessed: 2018, September 13).

Adams, J. S. (1998). The dynamics of integration Russia and near abroad. The Journal of Post-Soviet Democratization, 6(1), 50-64.

Alagappa, M. (1989, June). US-ASEAN security relations: challenges and prospects. Contemporary Southeast Asia, 11(1), 1-39.

Alisauskiene, R. (2017). Public opinion survey residents of Kyrgyzstan, International Republican Institute, February 15-March 2, 60. Retrieved from http://siar-consult.com/wp-content/uploads/2017/04/KyrgyzstanPoll-Winter-2017-Public.pdf (Accessed: 2018, September 15).

Ataman, M. (ed). (2018, Fall). The Struggle over Central Asia: Chinese-Russian Rivalry and Turkey's Comeback. Special edition of Insight Turkey, 20(4), Retrieved from https://www.insightturkey.com/issues/2018/20/4 (Accessed: 2019, January 3).

Atik, S. (2014). Regional economic integrations in the Post-Soviet Eurasia: an analysis on causes of inefficiency. Procedia Social and Behavioral Sciences, 109, 1326-1335.

Balassa, B. (1961). The theory of economic integration. Homewood, Illinois: Richard D. Irwin.

Baogang, H. (2017). Contested ideas of regionalism in Asia, New York: Routledge.

Bartlett, D. L. (2001). Economic development in newly independent states: the case of regionalism. The European Journal of Development Research, 13, 135-153.

BBC Uzbek, (2013, December 24). Nazarboyev Avrosiyo iqtisodiy ittifoqini siyosiylashtirishga qarshi chiqdi [Nazarbayev stands against the politicization of Eurasian economic union]. Retrieved from http://www. bbc.co.uk/uzbek/central_asia/2013/12/131224_cy_nazarbayev_union.shtml. (Accessed: 2015, April 24).

Beech, H. (2018, August 20). "We cannot afford this": Malaysia pushes back against China's vision. The New York Times. Retrieved from https://www.nytimes.com/2018/08/20/world/asia/china-malaysia.html (Accessed: 2018, September 15).

Beloff, M. (1963). The United States and the unity of Europe, London: Vintage Books ; Beugel, E. (1966). From Marshall Plan to Atlantic partnership: European integration as a concern of American policy. Amsterdam: Elsevier Publishing Company.

Berkofsky, A. (2012, July). China's strategic involvement in Central Asia: strategies, results and obstacles. ISPI, 128. Retrieved from https://www.ispionline.it/it/documents/Analysis_128_2012.pdf (Accessed: 2018, September 13).

Bhagwati, J. (1993). Regionalism and multilateralism: an overview. In Melo. D. J. and Panagariya A. (Eds.), New dimensions in regional integration (pp. 22-51), Cambridge: Cambridge University Press.

Bilal, S. (2013). External influences on regional integration in West Africa: the role of third parties", in Sohn R. and Oppong, A. K. (Eds.), Regional Trade and Monetary Integration in West Africa and Europe (pp.33-55). Bonn: WAI-ZEI Paper 6.

Bills, N. (2014). Powering a New Silk Road: helping connect supply with demand in South and Central Asia. USAID Frontlines Magazine, November-December edition. Retrieved from https://2012-2017.usaid. gov/news-information/frontlines/afghanistan/powering-new-silk-road-helping-connect-supplydemand-south (Accessed: 2018, September 05).

Blank, S. (2012). Whither the new great game in Central Asia? Journal of Eurasian Studies, 3(2), pp.147-160.

Bobokulov, I. (2006). Central Asia: is there an alternative to regional integration. Central Asian Survey, 25, 75-91.

Breslin, Sh. at al. (2002). New regionalisms in the global political economy, London: Routledge.

Buzan, B. and Wæver, O. (2003). Regions and powers: The structure of international security. Cambridge: Cambridge University Press.

Callahan, W. A. (2016). China's "Asia Dream": the Belt Road Initiative and the new regional order. Asian Journal of Comparative Politics, 1(3), pp. 226-243.

Chen, X. and Fazilov, F. (2018). Re-centering Central Asia: China's "New Great Game" in the old Eurasian heartland. Palgrave Communications, 4(71). DOI: 10.1057/s41599-018-0125-5

Cheng, Y. (2015). The Eurasian moment in global politics: a comparative analysis of great power strategies for regional integration. In P. Dutkiewicz and R. Sakwa (eds.), Eurasian integration - the view from within (pp.274-290). London and New York: Routledge. 
China National Petroleum Corporation. (2014). Flow of natural gas from Central Asia. Retrieved from http:// www.cnpc.com.cn/en/FlowofnaturalgasfromCentralAsia/FlowofnaturalgasfromCentralAsia2.shtml (Accessed: 2018, September 15).

Clover, Ch. (2012, December 7). Clinton vows to thwart new Soviet Union. The Financial Times. Retrieved from https://www.ft.com/content/a5b15b14-3fff-11e2-9f71-00144feabdc0 (Accessed: 2018, September 6).

Cochrane, J. D. (1964). United States attitudes toward Central American economic integration. Inter-American Economic Affairs, 18, 73-91.

Cochrane, J. D. and Sloan, J. W. (1973). LAFTA and the CACM: a comparative analysis of integration in Latin America. The Journal of Developing Areas, 8(1), 13-38.

Cooley, A. and Spruyt, H. (2009). Contracting states: sovereign transfers in international relations, Princeton: Princeton University Press.

Costea, A. and Langenhove, V. L. (2007). EU's foreign policy identity: from "new regionalism" to third generation regionalism? In Bain, J. and Holland, M. (Eds.), European Union identity (pp.86-104). Baden: Nomos.

Denha, R. E. (1969). The Role of the U.S. as an external actor in the integration of Latın Amerıca. Journal of Common Market Studies, 7(3), 199-216.

Deutsch, K. et al. (1957). Political community and the North Atlantic area. In Brent F. N. and Stubb, A. (eds.), 2003. The European Union: readings on the theory and practice of European integration (pp.115-138). Third edition. Palgrave Macmillan.

Diwakar, A. (2018, August 10). China's debt-trap diplomacy along the Belt and Road. The Wire. Retrieved from https://thewire.in/world/china-debt-trap-diplomacy-bri (Accessed: 2018, September 13).

Dragneva R. and Wolczuk, K. (eds). (2013) Eurasian economic integration: law, policy and politics. Cheltenham: Edward Elgar.

Dragneva, R. and Wolczuk, K. (2017, May). The Eurasian Economic Union - deals, rules and the exercise of power. Chatham House. Retrieved from https://www.chathamhouse.org/sites/default/files/publications/ research/2017-05-02-eurasian-economic-union-dragneva-wolczuk.pdf (Accessed: 2018, September 11).

Dutkiewicz, P. and Sakwa, R. (eds). (2015). Eurasian integration: the view from within. London and New York: Routledge.

Economist, (2015, April 11). Where all Silk Roads lead. Retrieved from http://www.economist.com/news/ china/21648039-through-fog-hazy-slogans-contours-chinas-vision-asia-emerge-where-all-silkroads (Accessed: 2018, September 5).

EDB. (2016). EDB integration barometer-2016, EDB Centre for Integration Studies, Saint Petersburg, 7. Retrieved from https://eabr.org/upload/iblock/9f5/edb_centre_2016_integration_barometer_presentation_ eng_1_.pdf (Accessed: 2018, September 15).

EDB. (2017). EDB integration barometer-2017, EDB Centre for Integration Studies, Saint Petersburg, 19-20. Retrieved from https://eabr.org/upload/iblock/3ef/EDB-Centre_2017_Report-46_EDB-IntegrationBarometer_ENG_2.pdf (Accessed: 2018, September 15).

El-Agraa, A. M. (1999) Regional Integration: Experience, Theory and Measurement, London: Palgrave Macmillan.

Fawcett, L. and Hurrell, A. (1995). Regionalism in world politics: regional organization and international order. Oxford: Oxford University Press.

Ferguson R. J. (2018). China's Eurasian dilemmas: Roads and risks for a sustainable global power. Cheltenham: Edward Elgar Publishing.

Fernholz, T. (2018, March 7). Eight countries in danger of falling into China's "debt trap. Quartz. Retrieved from https://qz.com/1223768/ (Accessed: 2018, September 13).

Fung Business Intelligence Centre, (2015, May). The Silk Road Economic Belt and the 21st Century Maritime Silk Road. Retrieved from https://www.fbicgroup.com/sites/default/files/The\%20Silk\%20Road\%20 Economic\%20Belt\%20and\%2021st\%20Century\%20Maritime\%20Silk\%20Road\%20MAY\%2015.pdf (Accessed: 2018, September 6).

Geyikdagi, N. V. (2005). Regional integration in Central Asia, Journal of Asia Pacific Business, 6(4), 61-74.

Haas, E. (1970). The Study of regional integration: reflections on the Joy and Anguish of pretheorizing. International Organization, 24(4), 607-646.

Haas, E., (1958). The uniting of Europe: political, social, and economic forces 1950-1957. Second edition. Stanford: Stanford University Press.

Hashimova, U. (2018, August 13). Why Central Asia is betting on China's Belt and Road. The Diplomat. Retrieved from https://thediplomat.com/2018/08/why-central-asia-is-betting-on-chinas-belt-and-road/ (Accessed: 2018, September 13). 
He, A. (2015, March 31). Silk Road connects China to the world. China Daily USA. Retrieved from http://usa. chinadaily.com.cn/us/2015-03/31/content_19965235.htm. (Accessed: 2018, September 12).

Hettne, B. (1993). Neo-mercantilism: the pursuit of regionness. Cooperation and Conflict, 28(3), 211-232.

Hettne, B. (2005). Beyond the "new" regionalism", New Political Economy, 10(4), 543-571.

Hettne, B., Inotai, A. and Sunkel, O. (Eds). (1999). Globalism and the new regionalism. Basingstoke: Macmillan.

Hodzi, O. and Chen, Y. (2017, October). The great rejuvenation? China's search for a new "global order. Institute for Security and Development Policy. Retrieved from http://isdp.eu/content/uploads/2016/11/2017-asiapaper-hodzi-chen-the-great-rejuvenation.pdf (Accessed: 2018, September 13).

Hoffmann, A. and Kfuri, R. (2007). The role of external actors upon regional integration: the US, the EU and

Hoffmann, S. (1966). Obstinate or obsolete? The fate of the nation-state and the case of Western Europe. Daedalus, 95 (3), 862-915.

Huang Y. (2016). Understanding China's Belt \& Road Initiative: Motivation, framework and assessment. China Economic Review, 40, pp.314-321.

Huang, C. (2015). 57 nations approved as founder members of China-led AllB, South China Monitoring Post. Retrieved from http://www.scmp.com/news/china/diplomacy-defence/article/1766970/swedenisrael-poland-and-south-africa-last-join-aiib (Accessed: 2018, September 6).

Hurley, J., Morris, S. and Portelance, G. (2018, March). Examining the debt implications of the Belt and Road Initiative from a policy perspective. CGD Policy Paper, 121. Retrieved from https://www.cgdev.org/sites/ default/files/examining-debt-implications-belt-and-road-initiative-policy-perspective.pdf (Accessed: 2018, September 13).

Hurrel, A. (1995). Explaining the resurgence of regionalism in world politics. Review of International Studies, 21(4), 331-358.

International Crisis Group, (2017). Central Asia's Silk Road Rivalries. Europe and Central Asia Report, 245.

Irnazarov, F. and Salmanov, Z. (2011). Regional Integration in Central Asia: Measuring the Perceptions of Economic Actors in Uzbekistan and Kazakhstan. Norwegian Institute of International Affairs (NUPI), Regional Competence-Building for Think-Tanks in the South Caucasus and Central Asia Project Report. Retrieved from Salmanov's personal profile at Academia.edu (Accessed: 2018, September 6).

Ivakhnyuk, I. (2006, June 28). Migration in the CIS region: common problems and mutual benefits. International Symposium on International Migration and Development. Population Division of the Department of Economic and Social Affairs of the United Nations Secretariat, Turin, Italy. Retrieved from https:// www.un.org/esa/population/migration/turin/Symposium_Turin_files/P10_SYMP_Ivakhniouk.pdf (Accessed: 2018, September 6)

Jacob, P. E. and Teune, H. (1964). The integrative process: guidelines for analysis of the bases of political community. In Jacob, P. E. and James, V. T. (eds.), The integration of political communities (pp.1-45). Philadelphia: Lippincott.

Kabananiye, A. (2011). Regional integration and sustainable growth in sub-Sahara Africa: a case study of the East Africa Community (Doctoral dissertation). Retrieved from Northumbria University Northumbria Research Link http://nrl.northumbria.ac.uk/2115/ (Accessed: 2018, September 6).

Kaczmarski, M. (2017). Non-western visions of regionalism: China's New Silk Road and Russia's Eurasian Economic Union. International Affairs, 93(6), pp.1357-1376. doi: 10.1093/ia/iix182

Kavalski, E. (ed). (2010). The new Central Asia: the regional impacts of international actors. Singapore: New Scientific Publishing.

Kim, Y. and Blank, S. (2013). Same Bed, Different Dreams: China's 'peaceful rise' and Sino-Russian rivalry in Central Asia. Journal of Contemporary China, 22(83), pp.773-790.

Laruelle, M. (ed). (2018). Chına's Belt and Road Initiative and Its Impact in Central Asia. Washington, D.C.: The George Washington University.

Laruelle, M. et al. (2010). China and India in Central Asia: A New "Great Game"?. New York: Palgrave Macmillan.

Libman, A. (2009). Regionalization in Central Asia. In Vinokurov E. (Ed.), Eurasian integration yearbook 2009 (pp.95114). Almaty: EDB.

Libman, A. and Vinokurov, E. (2011). Is it really different? Patterns of regionalization in the Post-Soviet Central Asia. Post-Communist Economies, 23 (4), 469-492.

Libman, A.M. (2006). The role of economic integration and disintegration in the post-Soviet space: A quantitative analysis. Studies on Russian Economic Development, 17(5), 498-507.

Lindberg, L. N. (1963). The Political dynamics of European economic integration. Stanford: Stanford University Press. 
Linn, J. (2012). Central Asian regional integration and cooperation: reality or mirage? In Vinokurov E. (Ed.), Eurasian integration yearbook 2012 (pp.96-117). Almaty: EDB.

Lombaerde, P. and Söderbaum, F. (2013). Reading the intellectual history of regionalism. In Philippe De Lombaerde and Fredrik Söderbaum (Eds.), Regionalism: four-volume set (pp. xvii-xlviii). London: SAGE Publications.

Lukin, Mikhail. (2007, May 21). Vse Rossiyskiye bazy [All Russian military bases]. Kommersant. Retrieved from http://www.kommersant.ru/doc/766827 (Accessed: 2018, September 6).

Machlup, F. (1977). A history of thought on economic integration. New York: Columbia University Press.

Marinov, E. (2013). Impact of the European Union on regional integration in Africa. In Financial and monetary economics - EFM 2013 (pp.229-239). Centre for Financial and Monetary Research at the Romanian Academy.

Mattli, W. (1999). The logic of regional integration: Europe and beyond. United States: University Press Durham.

Mattli, W. (2012).Comparative regional integration: theoretical developments. In Jones, E., Menon, A. and Weatherill, S. (Eds.), The Oxford handbook of the European Union (pp.777-792). Oxford: Oxford University Press.

MERCOSUR. The European Consortium for Political Research (ECPR), 20-21.

Metcalf, L. K. (1997). The (re) emergence of regional economic integration in the former Soviet Union. Political Research Quarterly, 50(3), 529-549.

Ministry of Foreign Affairs of P.R.C. (2015, March 28). Vision and Actions on Jointly Building Silk Road Economic Belt and 21st-Century Maritime Silk Road. Retrieved from http://www.fmprc.gov.cn/mfa_eng/ zxxx_662805/t1249618.shtml (Accessed: 2018, September 6).

Moravcsik, A. (1993). Preferences and power in the European Community: a liberal intergovernmental approach, Journal of Common Market Studies, 31(4), 473-523.

Moravcsik, A. (1998). The Choice for Europe: Social Purpose and State Power from Messina to Maastricht. NY: Cornell University Press.

Muntschick, J. (2018). The Southern African Development Community (SADC) and the European Union (EU): regionalism and external influence. Cham: Palgrave Macmillan.

Muntschick, J. (2013). Explaining the influence of extra-regional actors on regional economic integration in Southern Africa: the EU's interfering impact on SADC and SACU", In Lorenz-Carl, U. and Rempe, M. (Eds.), Mapping agency: comparing regionalisms in Africa (pp.77-95). First Edition, London: Routledge.

Muzalevsky, R. (2016, April 27). China's long march into Central Asia. Stratfor. Retrieved from https://worldview. stratfor.com/article/chinas-long-march-central-asia (Accessed: 2018, September 12).

Mytelka, L. K. (1973). Foreign aid and regional integration: the UDEAC case", Journal of Common Market Studies, 12(2), 138-158. Retrieved from https://doi.org/10.1111/j.1468-5965.1973.tb00693.x (Accessed: 2018, September 15)

Novikova, A. (2011, November 17). Yevraziyskiye komissary poluchat status federal'nykh ministrov [The Eurasian commissioners will receive the status of federal ministers]. Izvestiya. Retrieved from http://izvestia.ru/ news/507125 (Accessed: 2018, September 6).

Nye, J. S. (1968). Comparative regional integration: concept and measurement. International Organization, 22 (4), 855-880.

Olimova, S. (2015, March 17). Tajikistan's prospects of joining the Eurasian Economic Union. Russian Analytical Digest, 165, 13. Retrieved from https://doi.org/10.3929/ethz-a-010421380 (Accessed: 2018, September 15).

Page, J. (2014). China to contribute $\$ 40$ billion to Silk Road Fund, The Wall Street Journal. Retrieved from http:// www.wsj.com/articles/china-to-contribute-40-billion-to-silk-road-fund-1415454995 (Accessed: 2018, September 6).

Parker, S. and Chefitz, G. (2018, May). Debtbook diplomacy: China's strategic leveraging of its newfound economic influence and the consequences for U.S. foreign policy. Belfer Center for Science and International Affairs. Retrieved from https://www.belfercenter.org/sites/default/files/files/publication/Debtbook\%20 Diplomacy\%20PDF.pdf (Accessed: 2018, September 13).

Plummer, M. G. (2017). US-ASEAN relations in a changing global context. In Echle, Ch., Sarmah M. and Kliem F. (Eds.), ASEAN at 50: a look at its external relations (pp.139-151). Singapore: Konrad Adenauer Stiftung Ltd.

Pomfret, J. (2018, August 27). China's debt traps around the world are a trademark of its imperialist ambitions. Washington Post. Retrieved from https://www.washingtonpost.com/news/global-opinions/ wp/2018/08/27/chinas-debt-traps-around-the-world-are-a-trademark-of-its-imperialistambitions/?noredirect=on\&utm_term=.5951d736b438 (Accessed: 2018, September 13). 
Puchala, D. (1971). Of blind men, elephants and international integration. Journal of Common Market Studies, 10 (3), 267-284.

Putin, V. V. (2011, October 3). Novyy integratsionnyy proyekt dlya Yevrazii - budushcheye, kotoroye rozhdayetsya segodnya [A New integration project for Eurasia: a future that is born today]. Izvestiya. Retrieved from http://www.izvestia.ru/news/502761 (Accessed: 2018, September 6).

Qoraboyev, I. (2010). From Central Asian regional integration to Eurasian integration space? Changing dynamics of the Post-Soviet regionalism. In Vinokurov E. (Ed.), Eurasian integration yearbook 2010 (pp.206-232). Almaty: EDB.

Rakhimov, M. (2010). Internal and external dynamics of regional cooperation in Central Asia. Journal of Eurasian Studies, 1, 95-101.

Roberts, S.P. and Moshes, A. (2016). The Eurasian Economic Union: a case of reproductive integration? Post-Soviet Affairs, 32(6), 542-565.

Rozman, G. (2004). Northeast Asia's stunted regionalism: Bilateral distrust in the shadow of globalization. Cambridge: Cambridge University Press.

Rumer, E., Trenin, D. and Zhao, H. (2007). Central Asia: views from Washington, Moscow and Beijing. Armonk and London: ME Sharpe.

Sarsenbaeva, M. (2013, April 25). Foreign economic cooperation between Kazakhstan and China: Prioritie, Eurasian Economic Club of Scientists Association. Retrieved from http://group-global.org/ru/node/4450 (Accessed: 2018, September 6).

Shaw, T., Grant, A. J. and Cornelissen, S. (2011). The Ashgate research companion to regionalisms. Farnham: Ashgate.

Shen, S. and Chan, W. (2018, March 27). A comparative study of the Belt and Road Initiative and the Marshall Plan. Palgrave Communications, 4(32). DOI: 10.1057/s41599-018-0077-9

Silk Road Strategy Act of 1999, US Congress. No. 247. 106 $6^{\text {th }}$ Congress. $1^{\text {th }}$ Session. H. R. 1152 (1999, August 3). Retrieved from https://www.gpo.gov/fdsys/pkg/BILLS-106hr1152pcs/pdf/BILLS-106hr1152pcs.pdf (Accessed: 2018, September 6).

Söderbaum, F. (2016). Old, new, and comparative regionalism: the history and scholarly development of the field. In Börzel, T. and Risse, T. (Eds.), The Oxford handbook of comparative regionalism. Oxford: Oxford University Press.

Sputnik, (2013, October 7). Russian Army Base Deal with Tajikistan Key to Regional Security. Retrieved from https:// sptnkne.ws/j3MR (Accessed: 2018, September 6).

Standish, R. (2014, September 29). The United States' Silk Road to Nowhere, Foreign Policy. Retrieved from http://foreignpolicy.com/2014/09/29/the-united-states-silk-road-to-nowhere-2/ (Accessed: 2018, September 6).

Starr, S. F. (2005a). A Greater Central Asia partnership for Afghanistan and its neighbors, Central Asia-Caucasus Institute and Silk Road Studies Program. Silk Road Papers. Washington D.C.

Starr, S. F. (2005b). A Partnership for Central Asia, Foreign Affairs, 84(4). Retrieved from https://www.foreignaffairs. com/articles/asia/2005-07-01/partnership-central-asia (Accessed: 2018, September 6).

Stec, G. (2018, February). China's Belt and Road Initiative is neither a strategy, nor a vision. It is a process. European Institute for Asian Studies. Retrieved from http://www.eias.org/wp-content/uploads/2016/03/EU_ Asia_at_a_Glance_Stec_BRI_2018-1.pdf (Accessed: 2018, September 12).

Svetlicinii, A. (2018). China's Belt and Road Initiative and the Eurasian Economic Union: "integrating the integrations". Public Administration Issues, pp.7-20. DOI: 10.17323/1999-5431-2018-0-5-7-20.

Swanström, N. and Nyrén, P. (2017, January 4). China's march west: pitfalls and challenges in Greater Central Asia. Institute for Security and Development Policy, 195. Retrieved from http://isdp.eu/content/ uploads/2017/01/No.195.pdf (Accessed: 2018, September 13).

Tang, S. (2000). Economic integration in Central Asia: the Russian and Chinese relationship. Asian Survey, 40 (2), 360-376.

Tengri News, (2013, October 2). Lukashenko ne vidit neobkhodimosti v yedinoy valyute i politicheskoy nadstroyke $v$ YEES [Lukashenka sees no need for a single currency and political superstructure in the EAEU]. Retrieved from http://tengrinews.kz/sng/lukashenko-vidit-neobhodimosti-edinoy-valyute-politicheskoynadstroyke-ees-242805/ (Accessed: 2018, September 6).

The Economist. (2018, September 6). The perils of China's "debt-trap diplomacy. Retrieved from https://www. economist.com/asia/2018/09/08/the-perils-of-chinas-debt-trap-diplomacy (Accessed: 2018, September 13).

Tong, G. Ch. (2000, September 7). ASEAN-US relations: challenges. Asia Society. Retrieved from https://asiasociety. org/asean-us-relations-challenges (Accessed: 2018, September 10). 
Trilling, D. (2011, December 9). Uzbekistan's Karimov lashes out at Putin's Union, EurasiaNet. Retrieved from https://www.eurasianet.org/uzbekistans-karimov-lashes-out-at-putins-union (Accessed: 2018, September 6).

US Department of Defense. (2018). Annual report to Congress: military and security developments involving the People's Republic of China, Report. p.i. Retrieved from https://media.defense.gov/2018/ Aug/16/2001955282/-1/-1/1/2018-CHINA-MILITARY-POWER-REPORT.PDF (Accessed: 2018, September 15).

UzA. (2017, May 18). O'zbekiston Respublikasi va Xitoy Xalq Respublikasining har tomonlama strategik sheriklik munosabatlarini yanada chuqurlashtirish to'g'risida qo'shma bayonoti [Joint statement of the Republic of Uzbekistan and the People's Republic of China on further deepening of strategic partnership]. Retrieved from http://uza.uz/uz/politics/o-zbekiston-respublikasi-va-xitoy-xalq-respublikasining-har--18-052017?month=6\&year=2017\&sphrase_id=2344930\&ELEMENT_CODE=o-zbekiston-respublikasi-vaxitoy-xalq-respublikasining-har--18-05-2017\&SECTION_CODE=politics\&bxajaxid=7a95025902f2110 f0a021324d87641cf (Accessed: 2018, September 13).

Valovaya, T. (2012). Eurasian economic integration: origins, patterns, and outlooks. In Vinokurov E. (Ed.), Eurasian integration yearbook 2012 (pp.42-61). Almaty: EDB.

Voloshin, G. (2012, September 24). Russia's Eurasian Union: A Bid for Hegemony?, Geopolitical Monitor. Retrieved from http://www.geopoliticalmonitor.com/russias-eurasian-union-a-bid-for-hegemony-4730. (Accessed: 2018, September 6).

Voloshin, G. (2017, May 24). Central Asia ready to follow China's lead despite Russian ties. Eurasia Daily Monitor, 14(71). Retrieved from https://jamestown.org/program/central-asia-ready-follow-chinas-leaddespite-russian-ties/ (Accessed: 2018, September 13).

Wang, H. (2018). Divergence, convergence or crossvergence of Chinese and US approaches to regınal integration: Evolvıng trajectorıes and their implications. Tsinghua China Law Review, 10(2), pp.149-185.

Weitz, R. (2015, March 4). U.S. New Silk Road Initiative Needs Urgent Renewal, CACl Analyst. Retrieved from http:// www.cacianalyst.org/publications/analytical-articles/item/13155-us-new-silk-road-initiativeneeds-urgent-renewal.html (Accessed: 2018, September 6).

Wirminghaus, N. (2012). Ephemeral regionalism: the proliferation of (failed) regional integration initiatives in PostSoviet Eurasia. In Börzel T. A., Goltermann, L., Lohaus, M. and Striebinger K. (Eds.), Roads to regionalism. genesis, design, and effects of regional organizations (pp. 25-44). Ashgate.

Wishnick, E. (2009). Russia, China, and the United States in Central Asia: Prospects for Great Power Competition and Cooperation in the Shadow of the Georgian Crisis. Strategic Studies Institute. Retrieved from https://ssi. armywarcollege.edu/pdffiles/PUB907.pdf (Accessed: 2019, September 3).

Wolff, L. Ch. (2016). China's "Belt and Road" Initiative - an introduction. In Wolff L. Ch. and Xi, Ch. (Eds.), Legal dimensions of China's Belt and Road Initiative (pp.1-31). Wolters Kluwer.

Wu, H. L. and Chen, C. H. (2004). The prospects for regional economic integration between China and the five Central Asian countries, Europe-Asia Studies, 56 (7), 1059-1080.

Xidirov, Q. (2017, May 17). O'zbekiston-Xitoy hamkorligi yangi bosqichga chiqmoqda [Uzbek-Chinese cooperation is rising to a new level]. Xalq So'zi. Retrieved from http://old.xs.uz/index.php/homepage/sijosat/ item/10179-zbekiston-khitoj-amkorligi-yangi-bos-ichga-chi-mo-da (Accessed: 2018, September 13).

Xinhua. (2013, October 16). China-Central Asia trade accelerates. Retrieved from http://english.people.com.cn/ business/8427374.html (Accessed: 2018, September 6).

Xinhua. (2014). How can the world be win-win? China is answering the question. Retrieved from http://news. xinhuanet.com/world/2014-05/08/c_1110604423.htm (Accessed: 2018, September 6).

Xinhua. (2017, September 1). China, Tajikistan agree to forge comprehensive strategic partnership. Retrieved from http://www.xinhuanet.com/english/2017-09/01/c_136572054.htm (Accessed: 2018, September 13).

Ye, M. (2015). China and competing cooperation in Asia-Pacific: TPP, RCEP, and the New Silk Road. Asian Security, 11(3), pp. 206-224.

Zhengyuan, X. (2010). In the shadow of great powers: a comparative study of various approaches to regionalism in Central Asia. Connections, 9(4), 37-52. 